\title{
Les femmes dans Nouvelles de Nulle Part
}

Women in News from Nowhere

\section{Catherine Durieux}

\section{OpenEdition}

\section{Journals}

Édition électronique

URL : http://journals.openedition.org/rfcb/3277

DOI : $10.4000 /$ rfcb.3277

ISSN : 2429-4373

Éditeur

CRECIB - Centre de recherche et d'études en civilisation britannique

\section{Édition imprimée}

Date de publication : 1 septembre 2004

ISBN : 2-911580-19-2

ISSN : 0248-9015

\section{Référence électronique}

Catherine Durieux, "Les femmes dans Nouvelles de Nulle Part», Revue Française de Civilisation

Britannique [En ligne], XIII-1 | 2004, mis en ligne le 01 septembre 2004, consulté le 08 octobre 2019. URL : http://journals.openedition.org/rfcb/3277 ; DOI : 10.4000/rfcb.3277

Ce document a été généré automatiquement le 8 octobre 2019.

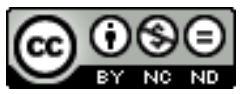

Revue française de civilisation britannique est mis à disposition selon les termes de la licence Creative Commons Attribution - Pas d'Utilisation Commerciale - Pas de Modification 4.0 International. 


\title{
Les femmes dans Nouvelles de Nulle Part
}

\author{
Women in News from Nowhere
}

Catherine Durieux

1 Je commencerai par situer News From Nowhere ${ }^{1}$ dans ce que George Orwell a appelé « la chaîne des utopies » : News from Nowhere est écrit en réponse à une autre utopie, Looking Backward (1888) ${ }^{2}$, de l'Américain Edward Bellamy, avant de susciter à son tour sa propre réponse avec A Modern Utopia (1905) de H. G. Wells ${ }^{3}$. L'importance du roman dans l'histoire de l'utopie est très grande et a été généralement reconnue comme telle: comme Marie-Louise Berneri ${ }^{4}$, mais pour des raisons différentes, Arthur Leslie Morton ${ }^{5}$ met News from Nowhere plus haut que tout, y voyant le mariage réussi de la théorie marxiste et des vieilles aspirations populaires au pays de cocagne. Les sommes classiques de Raymond Trousson ${ }^{6}$ et de Frank et Fritzie Manuel ${ }^{7}$ réservent aussi une belle place à News from Nowhere, tandis que Raymond Ruyer souligne que «l'utopie de William Morris est à peine une utopie, en ce sens qu'elle ne contient pas, ou presque pas, d'exercice utopique. C'est un rêve, une Arcadie $»^{8}$. Comme le remarque Stephen Arata, Morris s'emploie à rendre tangible, sensuellement perceptible, sa vision, dans le but de séduire et non de persuader". La critique que Bellamy fait de News from Nowhere dans The New Nation - en écho à celle que Morris a fait de Looking Backward dans Commonweal - manque donc singulièrement de pertinence :

Such glimpses as we are given... pique our curiosity ... In the stores and markets everybody takes what he wants and as much of it as he wishes, and that is all there is about it. This is delightful, ... We simply wish very much that Mr. Morris had told us more about the system. ${ }^{10}$

2 Bellamy manque complètement la spécificité de l'œuvre, qui est d'être une évocation et non une exposition du communisme futur. Il fait preuve d'acuité, en revanche, à propos de la construction des personnages féminins :

There is one sort of crime which Mr. Morris gives us slight hopes of ever getting rid of, - homicide growing out of love quarrels. If, indeed, the women are going to be so distractingly lovely in the new age as Mr. Morris describes them, the men are 
scarcely to be blamed for losing their wits over them. Upon this theme he dwells with all a poet's enthusiasm. ${ }^{11}$

Certains aspects de la vie privée de Morris, longtemps censurés mais remis en lumière aujourd'hui, permettent d'éclairer la place des femmes dans sa construction utopique ${ }^{12}$. Morris est un homme de son temps et la question de l'émancipation féminine occupe une large place au XIX siècle, sous le vocable français de "Question de la femme » et le vocable anglais de 'Woman's Question'. Le terme ne doit rien au hasard et il est important de le comprendre pour se garder de tout anachronisme ${ }^{13}$ : le singulier (woman plutôt que women) symbolise ce que l'époque perçoit comme l'unité essentielle du sexe féminin, tandis que le terme de "question » amène à se demander qui, justement, pose la question? Ne serait-ce pas les hommes ? Le possessif semblerait indiquer qu'au contraire, la question appartient à la femme, mais alors le fait pour les femmes d'envisager leur propre être comme une question ou comme un problème semblerait indiquer que le vocabulaire même qu'elles emploient est profondément masculin. Enfin, les majuscules donnent à ce vocable une solennité et un poids très particuliers.

De plus, la revendication du droit de vote des femmes commence à prendre de l'ampleur à cette époque et les premiers points sont marqués au niveau local avec la loi sur l'éducation de 1870, prévoyant l'élection par les contribuables des deux sexes des comités de gestion des écoles (School Boards) et la possibilité pour les femmes de se présenter à ces élections. En 1888, certaines obtiennent pour la première fois des droits proprement politiques: les femmes non mariées (les autres étant présumées représentées par leur époux) sont autorisées à voter aux élections des conseils de comtés et des conseils municipaux nouvellement créés. Annie Besant, de la Société fabienne, revendique le droit de vote pour tous les adultes à ces élections locales. Cela ne peut pas être une préoccupation de Morris dans la mesure où son utopie, par rapport à toutes celles qui précèdent et qu'il a à l'esprit quand il écrit - notamment Bellamy et More - se distingue par son côté libertaire. Les institutions de la démocratie représentative ont disparu, remplacées par une démocratie directe à laquelle il va de soi que tous les 'neighbours' participent. L'amour tient une place bien plus grande que la politique, tant dans l'intrigue que dans l'ordre des questions examinées, puisque c'est la première chose dont il est question lors de la longue conversation entre Guest et Hammond. C'est donc dans ce premier chapitre d'explications, 'Concerning Love', que Morris expose le plus longuement ce qu'il veut faire passer sur la question des femmes et des relations entre les sexes. Cependant, il sera intéressant d'examiner le reste de l'ouvrage à la recherche des non-dits et peut-être des impensés de l'auteur.

\section{Une utopie libertaire}

5 Le lecteur commence par apprendre que Dick a vécu deux ans avec Clara, qu'ils ont deux enfants, mais qu'elle l'a quitté pour un autre et qu'elle lui revient à présent. Tout cela est très osé pour l'époque et il convient d'abord de remarquer que Morris fait ici de la femme l'agent moteur du couple, qui part et qui revient, sans pour autant subir l'opprobre social dans la mesure où ses raisons d'agir sont légitimes. Ce passage est aussi l'occasion d'expliquer que le mariage classique a disparu, remplacé par ce que nous appellerions l'union libre et que l'époque victorienne appelait "amour libre $»^{14}$ (mais Morris n'emploie pas le terme, se contentant d'exposer la chose). Le mariage n'existant plus, le divorce a également cessé d'être : en fin de compte, les jugements de 
divorce ne réglaient que des questions de gros sous dans la mesure où aucun tribunal ne peut forcer au respect d'un contrat sentimental, comme le rappelle Hammond. Morris ne développe pas davantage, mais c'est assez pour reconnaître en filigrane l'analyse marxiste. Pour Bebel dans La Femme dans le passé, le présent et l'avenir ${ }^{15}$ et Engels dans L'origine de la famille, de la propriété privée et de l'État ${ }^{16}$, c'est l'avènement de la propriété qui a engendré le patriarcat, la famille monogamique et l'inégalité des sexes. En l'absence de propriété privée, la superstructure institutionnelle du mariage et du divorce n'a donc plus de raison d'être. Dans News from Nowhere, Morris explique qu'une grande partie des violences - les crimes passionnels - a disparu avec l'idée de la propriété de l'homme sur la femme :

Many violent acts came from the artificial perversion of the sexual passions, which cause over-weening jealousy and the like miseries. Now, when you look carefully into these, you will find that what lay at the bottom of them was mostly the idea (a law-made idea) of the woman being the property of the man, whether he were husband, father, brother, or what not. That idea has of course vanished with private property, as well as certain follies about the 'ruin' of women for following their natural desires in an illegal way, which of course was a convention caused by the laws of private property. ${ }^{17}$

6 Pour autant, toute souffrance n'a pas disparu: 'We do not deceive ourselves, indeed, or believe that we can get rid of all the trouble that besets the dealings between the sexes ${ }^{18}$, nous dit Hammond. Des crimes passionnels peuvent encore se produire mais ils sont, selon Dick, des événements monstrueux et exceptionnels qui ne passent pas inaperçus :

Love is not a very reasonable thing, and perversity and self-will are commoner than some of our moralists think... Yes, only a month ago there was a mishap down by us, that in the end cost the lives of two men and a woman, and, as it were, put out the sunlight for us for a while. Don't ask me about it just now; I may tell you about it later on. ${ }^{19}$

7 Toutefois, comme Bellamy l'a fait remarquer dans sa critique de News from Nowhere, Morris se plaît à évoquer de tels événements monstrueux ${ }^{20}$. On en déduit donc que soit ces événements ne sont pas si exceptionnels, soit ils tiennent une grande place dans l'imaginaire de l'auteur. Morris insiste sur la question de la souffrance en amour puisqu'il met encore en scène le trouble sentimental de Dick et Clara, puis l'inquiétude de Clara qui craint qu'Ellen ne lui ravisse Dick, tandis qu'Hammond le vieux sage explique que le chagrin est souvent inséparable des joies de l'amour mais que la civilisation nouvelle encourage les gens à ne pas rester centrés sur leurs déboires amoureux $^{21}$. On ne peut s'empêcher de penser que c'est Morris souffrant qui parle par la bouche d'Hammond, Morris dont l'amour pour sa femme n'était pas payé de retour et qui a trouvé une certaine consolation dans une relation platonique avec Georgiana, la femme de son grand ami le peintre Edward Burne-Jones. Il convient peut-être de rappeler ici quelques éléments biographiques: Morris a épousé une très belle femme, issue du peuple, rencontrée alors qu'il était étudiant à Oxford. Jane Burden était la fille d'un palefrenier et ne pouvait guère partager les activités intellectuelles de Morris. En revanche, elle fut l'un des grands modèles préraphaélites. Le mariage ne marche pas et Morris doit supporter la longue liaison qu'elle entretient avec le peintre Dante Gabriel Rossetti et s'accommoder d'un ménage à trois discret (à Kelmscott Manor, sa maison dans l'Oxfordshire ${ }^{22}$ ) plutôt que d'exposer Jane à l'opprobre public et leurs filles au scandale. Cela explique peut-être que le thème de la femme infidèle revienne si souvent dans la fiction de Morris, que ce soit dans News from Nowhere avec Clara qui a quitté Dick, dans The Defence of Guinevere (1858), son premier recueil de poèmes, ou encore 
dans The Wood Beyond the World (1894), où l'infidélité et la méchanceté d'une femme sont à l'origine du voyage initiatique du héros. L'énergie créatrice et la puissance de travail dont Morris a fait preuve à un degré extraordinaire jusqu'à la fin de sa vie étaient sans doute un moyen pour lui de sublimer son énergie amoureuse et sexuelle. Il établit d'ailleurs un parallèle entre les deux dans News from Nowhere:

'If you are going to ask to be paid for the pleasure of creation, which is what excellence in work means, the next thing we shall hear of will be a bill sent for the begetting of children.'

'Well, but,' said I, 'the man of the nineteenth century would say there is a natural desire towards the procreation of children, and a natural desire not to work.'

'Yes, yes,' said he, 'I know the ancient platitude, - wholly untrue; indeed, quite meaningless. Fourier, whom all men laughed at, understood the matter better.'23

Dans sa critique de Looking Backward, Morris reproche à Bellamy de ne pas avoir tiré les conséquences ultimes du communisme puisqu'il maintient la structure familiale intacte $^{24}$. Lui la chamboule passablement en évoquant des enfants vivant ensemble plusieurs semaines dans les bois, des couples qui se défont et se reforment librement, et en précisant que les gens choisissent librement leur habitation en fonction de goûts partagés avec les autres occupants. Morris met donc en pratique son libertarisme sur le plan des relations sexuelles dans son utopie comme dans sa vie, avec une conséquence inattendue et quelque peu gênante pour le lecteur contemporain.

\section{Eugénisme libertaire}

9 Patrick Parrinder a affronté la question de l'eugénisme, restée longtemps un impensé des études consacrées à Morris ${ }^{25}$. L'idée d'amélioration eugénique est pourtant bien présente dans News from Nowhere:

Well, as to our looks, the English and Jutish blood, which on the whole is predominant here, used not to produce much beauty. But I think we have improved it... Now, there are some people who think it not too fantastic to connect this increase of beauty directly with our freedom and good sense in the matters we have been speaking of: they believe that a child born from the natural and healthy love between a man and a woman, even if that be transient, is likely to turn out better in all ways, and especially in bodily beauty, than the birth of the respectable commercial marriage bed, or of the dull despair of the drudge of that system. They say, Pleasure begets pleasure. ${ }^{26}$

Parrinder rattache l'eugénisme de Morris à celui de Grant Allen, tenant de l'amour libre qui écrit dans The Girl of the Future (1890, donc la même année que News from Nowhere) que des unions libres plutôt que contraintes par le code moral victorien produiraient des résultats eugéniques positifs. Plus généralement, il rattache Morris à un eugénisme de tradition libertaire, historiquement associé à des mouvements de libération tels l'amour libre, la contraception et le féminisme. J'insisterai sur cette tradition car elle est méconnue : qui sait que les pionniers du néo-malthusianisme et de la diffusion de la contraception, comme Marie Stopes en Grande-Bretagne ou Paul Robin en France, étaient aussi eugénistes? Victoria Woodhull, suffragiste américaine, première femme à se présenter à la présidence des États-Unis (en 1872, alors que les Américaines n'ont pas le droit de vote), socialiste marxiste peu orthodoxe, défend l'amour libre dans l'idée que seront sains les enfants nés d'une union saine basée sur l'amour et/ou le désir plutôt que sur l'intérêt ${ }^{27}$. Cette tradition d'eugénisme libéral, voire libertaire quand il est lié à la promotion de l'amour libre, s'oppose à l'eugénisme autoritaire incarné par 
Galton. Un passage de News from Nowhere suggère toutefois que l'eugénisme a pu y prendre une autre forme, moins libertaire :

"In times past, it is clear that the "Society" of the day helped its Judaic god, and the "Man of Science" of the time, in visiting the sins of the father upon the children. How to reverse this process, how to take the sting out of heredity, has for long been one of the most constant cares of the thoughtful men amongst us' ${ }^{28}$

11 Ce passage, qui semble indiquer une intervention humaine consciente en vue d'améliorer l'hérédité des individus, est toutefois trop isolé pour qu'on puisse en tirer la moindre conclusion. Je me contente donc ici, après Patrick Parrinder, de le signaler ${ }^{29}$. Tout aussi problématique pour le lecteur contemporain est la question de la division sexuelle du travail dans News from Nowhere, où les personnages féminins, à l'exception de la sculptrice Philippa, ne sont construits qu'en position de servir des hommes.

\section{La question problématique du travail domestique dans News from Nowhere}

12 Morris fréquentait la maison de la suffragette Emmeline Pankhurst et par ses activités socialistes il était en contact avec des femmes « publiques » comme Helen Taylor, Annie Besant et Eleanor Marx. Son idée de la femme reste cependant très victorienne : c'est la vision « enchantée » des peintres préraphaélites ${ }^{30}$. La belle Ellen, dame de Runnymede, recluse se consacrant à l'étude du monde, comparée à une fée, quittant la retraite où elle vit cachée des hommes pour remonter la Tamise dans une barque, évoque par certains aspects la Dame de Shalott du poème de Tennyson (1842) et surtout du tableau de Hunt: 'her lazy enjoyment of the new scene seemed to bring out her beauty doubly as she leaned back amidst the cushions. ${ }^{31}$ Emblématique aussi de cette vision enchantée pourrait être le groupe de jeunes filles - ou plutôt de nymphes - peu vêtues et pieds nus après leur baignade, s'ébattant dans l'herbe et hélant les voyageurs qui passent en bateau :

Down on the green lip of the river,... were half a dozen girls playing about on the grass. They hailed us as we were about passing them, as they noted that we were travellers and we stopped a minute to talk with them. They had been bathing and were light clad and barefooted, and were bound for the meadows on the Berkshire side, where the haymaking had begun, and were passing the time merrily enough till the Berkshire folk came in their punt to fetch them. ${ }^{32}$

Dans toutes les scènes d'auberge, les femmes s'affairent avec grâce et un doux sourire pour servir les voyageurs ${ }^{33}$. On ne voit pas de personnage de femme faire autre chose dans News from Nowhere. La sculptrice Philippa est une exception, mais le chapitre XXVI dont elle fait partie n'a été ajouté qu'en 1891 et son personnage n'est pas construit sans ambiguïté, comme nous le verrons plus tard. Pourtant, l'égalité des sexes semble aller de soi et être un acquis dans ce nouveau monde :

The men have no longer any opportunity of tyrannizing over the women, or the women over the men; both of which things took place in those old times. The women do what they can do best, and what they like best, and the men are neither jealous of it or injured by it. This is such a commonplace that I am almost ashamed to state it. ${ }^{34}$

14 Morris met ici sur le même plan le pouvoir des hommes sur les femmes et celui des femmes sur les hommes, ce qui revient à nier l'oppression dont ont été historiquement victimes les femmes. De plus, à la différence de Bellamy qui considère que le travail domestique est une corvée à épargner aux femmes, Morris considère que ce travail est 
pour les femmes et que ce travail est noble. C'est ce qui conduit Ruth Levitas à prendre intelligemment sa défense en soulignant que, dans l'analyse de Morris, les aspects négatifs du travail domestique proviennent des conditions dans lesquels les femmes exécutent ce travail, non de son caractère intrinsèque ${ }^{35}$. À l'objection de Guest, 'I saw at the Guest House that the women were waiting on the men: that seems a little like reaction, doesn't it? ${ }^{36}$, Hammond fait cette réponse :

'Does it? ... perhaps you think house-keeping an unimportant occupation, not deserving of respect. I believe that was the opinion of the "advanced" women of the nineteenth century and their male backers. If it is yours, I recommend to your notice an old Norwegian folk-lore tale called How the Man Minded the House... I am... laughing at... that silly nineteenth-century fashion, current among rich socalled cultivated people, of ignoring all the steps by which their daily dinner was reached, as matters too low for their lofty intelligence. Useless idiots! Come now, I am a "literary man", as we queer animals used to be called, yet I am a pretty good cook myself.' ${ }^{37}$

Hammond (et Guest après lui) revendiquent avec fierté le fait d'être bons cuisiniers. William Morris lui-même en était fier. Son entreprise, Morris \& Co., concevait et exécutait des objets décoratifs dans l'idée de mettre de l'art dans la vie quotidienne et d'effacer la distinction entre art et $\operatorname{artisanat}^{38}$. Ce n'est pas seulement le travail domestique que Morris entreprend de revaloriser dans News from Nowhere, mais tous les travaux manuels :

'Perhaps you have not learned to do these things I have been speaking about; and if that's the case, don't run away with the idea that it doesn't take some skill to do them, and doesn't give plenty of work for one's mind: you would change you opinion if you saw a Dorsetshire lad thatching, for instance'. ${ }^{39}$

Morris admire les sagas islandaises, dont les grands héros mythiques sont célèbres pour leurs exploits de forgerons autant que pour leurs exploits guerriers, dont les grands hommes n'hésitent pas à aider quand c'est nécessaire aux travaux des champs ${ }^{40}$. La sincérité de Morris n'est pas en doute et il faisait œuvre pionnière en se mêlant d'artisanat tout en étant un grand intellectuel, cependant son ambivalence et sa légère condescendance transparaissent à travers certaines remarques, comme celle-ci sous forme d'une boutade de Hammond :

'Come, now, my friend, ... don't you know that it is a great pleasure to a clever woman to manage a house skilfully, and to do it so that all the house-mates about her look pleased, and are grateful to her? And then, you know, everyboy likes to be ordered about by a pretty woman: why, it is one of the pleasantest forms of flirtation'. ${ }^{4}$

La boutade de Hammond offre la seule réponse possible à la question de savoir pourquoi ce n'est pas Hammond ou Guest qui s'occuperaient de la salle commune puisqu'ils se vantent d'être bons cuisiniers. Mais la vraie réponse suppose que l'on rétablisse la vérité en remplaçant 'everybody likes to be ordered about by a pretty woman' par 'everybody likes to be served by a pretty woman', car c'est bien de cela qu'il s'agit.

Dans le cadre de « la firme» (Morris \& Co.), les femmes des associés, dont Jane Morris, faisaient le travail le moins créatif et le plus répétitif. Comme le fait remarquer Fiona MacCarthy, les préraphaélites semblaient attirés par les femmes socialement (et donc aussi culturellement) inférieures, comme l'exprime le tableau de Burne-Jones «Le Roi Cophétua et la Jeune Mendiante» (1884) ${ }^{42}$. Mais à la différence de Rossetti et Lizzie Siddal, Holman Hunt et Annie Miller, Ford Madox Brown et Emma, Morris va jusqu'à épouser Jane ... pour sa beautét ${ }^{43}$. La mendiante à demi-nue assise sur le trône en 
hauteur, avec le roi en armure à ses pieds levant les yeux vers elle, est un excellent exemple de la "piédestalisation » de la femme qui a été reprochée aux préraphaélites et que l'on peut reprocher à William Morris ${ }^{44}$.

\section{Si femmes, si belles...} Nulle Part: 'Three young women were flitting to and fro. As they were the first of the sex I had seen on this eventful morning, I naturally looked at them very attentively, and found them at least as good as the gardens, the architecture, and the male men'. ${ }^{45}$ Dans la suite du texte, Guest s'extasie souvent sur la beauté des femmes ${ }^{46}$. Le texte insiste également sur le fait que le travail les embellit, comme lorsque Dick dit à Clara : 'We will manage to send you to bed pretty tired every night; and you will look so beautiful with your neck all brown, and your hands too, and you under your gown as white as privet ... our week's haymaking will do that for $\mathrm{you}{ }^{\prime 47}$. A contrario, un des grands inconvénients de la paresse (pratiquée par exemple par les intermédiaires tels que les commerçants qui selon Morris s'enrichissent sans travail) est qu'elle produit des femmes laides :

Well, these Idleness-stricken people used to serve booths all their time, because they were fit for so little. Indeed, I believe that at one time they were actually compelled to do some work, because they, especially the women, got so ugly and produced such ugly children if their disease was not treated sharply, that the neighbours couldn't stand it... I have seen some of those poor women grown old. But my father used to know some of them when they were young; and he said that they were as little like young women as might be: they had hands like bunches of skewers, and wretched little arms like sticks; and waists like hour glasses, and thin lips and peaked noses and pale cheeks; and they were always pretending to be offended by anything you said or did to them. No wonder they bore ugly children, for no one except men like them could be in love with them - poor things! ${ }^{48}$

Le travail créatif n'est toutefois pas très embellissant pour une femme : Philippa est une des rares femmes sans beauté rencontrées par Guest ... et elle est sculptrice. Elle est si prise par son travail que cela l'empêche d'être disponible et particulièrement aimable pour les visiteurs, ce qui la fait apparaître comme une anomalie. Elle s'insère d'ailleurs dans le chapitre sur 'The Obstinate Refusers' - les gens bizarres qui ne veulent pas participer à la fenaison - et elle est même responsable de cette exclusion volontaire puisque c'est à cause de sa maladie que le travail a pris du retard. Voilà ce qui arrive quand on compte sur une femme comme chef d'une équipe de sculpteurs ... À Philippa, Morris semble préférer un autre personnage de femme, le modèle de Philippa : 'A very pretty woman who was not in the work but was dressed in an elegant suit of blue linen came sauntering up to us with her knitting in her hand. She welcomed us and said, smiling ... ${ }^{49}$. Belle, nonchalante, souriante, amicale, elle passe à tricoter les heures où sa beauté n'est pas requise. Avec la broderie, qui éduque le goût, et l'arrangement floral, le tricot, censé favoriser sérénité et économie, faisait partie des loisirs recommandés aux femmes dans le cadre de l'idéologie de la "Vraie féminité " ${ }^{50}$. Bien que socialiste, Morris s'appuie sur ce fonds commun idéologique et les travaux et loisirs (les deux étant pour lui inséparables) qu'il envisage le plus volontiers pour les femmes de Nulle Part ressortissent donc de la sphère domestique. 


\section{Si femmes, si bonnes...}

21 La beauté chez les femmes de Nulle Part va de pair avec la bienveillance et la bonté. Elles sont sans cesse représentées en train de tapoter amicalement les hommes (ou parfois un animal ${ }^{51}$ ). Cela commence dès l'auberge, où l'une des trois femmes - la plus jolie, Annie - semble prendre Guest sous sa protection amicale: 'One of the girls, the handsome one, who had been scattering little twigs of lavender and other sweet-smelling herbs about the floor, came near to listen, and stood behind me with her hand on my shoulder'. ${ }^{52} \mathrm{Il}$ semble que Morris se contente de substituer à la vision victorienne de la femme comme 'ministering angel' son rêve plus personnel de 'ministering beauty'. Les petites tapes amicales ne sont qu'une manifestation du rôle privilégié des femmes de Nulle Part, dont Annie encore donne trois autres exemples consécutifs pendant sa courte présence sur scène en s'employant à dissiper la gêne occasionnée à Guest par la question de Robert, puis la gêne occasionnée à Robert par les railleries de Dick ${ }^{53}$, puis enfin en expliquant à Guest « d'un ton câlin ${ }^{54}$ » - là encore destiné à dissiper la gêne - que les autres rient parce qu'ils trouvent qu'il fait vieux La femme est posée dès le début du récit comme la beauté et la consolatrice de l'homme par excellence. Le summum est atteint avec Ellen, une beauté incomparable ${ }^{55}$, qui comprend que Guest est un voyageur dans le temps et décide de le suivre pour se consacrer à son bonheur: 'I wanted to make you as happy as you could be ... This evening, or tomorrow morning, I shall make a proposal to you to do something which would please me very much, and I think would not hurt you'. ${ }^{56}$ Quel genre de proposition peut-elle avoir en tête, sachant qu'elle veut œuvrer au bonheur de Guest? La réponse est donnée peu avant l'arrivée des voyageurs à destination : 'I was going to propose that you should live with us where we are going. I feel quite old friends with you, and should be sorry to lose you'. ${ }^{57}$ Le lecteur se perd en conjectures pour savoir si Ellen envisage de vivre avec Guest comme avec un second père ou comme avec un mari. La deuxième hypothèse serait plus agréable à Guest puisqu'il est amoureux, mais le texte ne permet pas de trancher car l'érotisme et la franche camaraderie y sont omniprésents et inséparables.

\section{Une fête des sens}

C.S. Lewis a été le premier à souligner la dimension érotique du texte. Outre que le texte est truffé de références à la beauté féminine, cette dimension passe notamment par le regard (masculin) et le rougissement que ce regard provoque. On sait que le rougissement est perçu au XIX $\mathrm{X}^{\mathrm{e}}$ siècle comme un phénomène non pas affectif mais physiologique, lié à la sexualité ${ }^{58}$. Le voyage initiatique de Guest commence avec Annie et se termine avec Ellen. Annie rougit sous son regard: 'She blushed a little under my gaze, though it was clear that she had taken me for a man of eighty'. ${ }^{59}$ De même avec Ellen: 'She caught my eye and her cheeks reddened under their tan'. ${ }^{60} \mathrm{Si}$ le regard est particulièrement important, d'autres sens peuvent être mis en éveil dans News from Nowhere, tels que l'ouïe : 'Her voice saying the very thing which I was thinking, was like a caress to me'. ${ }^{61} \mathrm{Le}$ toucher est beaucoup sollicité, mais la dimension érotique en est remarquablement absente: les incessantes petites tapes amicales, pareilles au geste d'une mère pour réconforter son enfant, instaurent un rapport de camaraderie entre les sexes. Les mains se joignent aussi beaucoup dans News from Nowhere ${ }^{62}$, mais là encore le geste n'a rien d'érotique, en tout cas pour les femmes qui le font : 'She [Clara] took my hand as an 
affectionate child would, and led me out of the room and down stairs into the forecourt of the Museum, leaving the two Hammonds to follow as they pleased'. ${ }^{63}$ Si Clara instaure avec Guest le même rapport qu'entre un vieux monsieur et sa petite-fille, lui ne semble pas voir les choses de la même façon : 'I thought it bad manners to stare at Clara all the time, though she was quite worth it'. ${ }^{64}$

Que ce soit avec Clara ou avec Annie dans l'exemple cité plus haut, Guest est projeté, en raison de sa vieillesse trop apparente, dans le rôle d'une sorte d'eunuque, mais dont la sexualité passe quand même par le regard. On peut sans doute parler d'un plaisir scopique chez Morris ${ }^{65}$ et rattacher ce mode de plaisir à des éléments biographiques : il a été peintre, marié à l'une des grandes beautés de l'époque, avec qui l'on peut supposer qu'il n'entretenait plus de rapports sexuels depuis longtemps étant donné leur désamour et la haute conception qu'il se faisait des rapports charnels ${ }^{66}$. L'importance du regard est aussi patente au niveau textuel et méta-textuel : c'est par le regard, ou plutôt son absence, que Guest s'efface de Nulle Part et que le récit prend fin, sur ces mots: 'If others can see it as I have seen it, then it may be called a vision rather than a dream'.67

\section{Conclusion}

Pour conclure, la vision des femmes dans News from Nowhere est fortement essentialiste dans la mesure où leur nature supposée semble diriger systématiquement les femmes vers un certain type de travaux et un certain comportement. Morris se rattache à une tradition rousseauiste étonnamment très influente dans le monde anglo-saxon, qui voit la femme comme une compagne (telle Sophie agrémentant la vie d'Émile), complémentaire de l'homme par ses qualités spécifiques, mais jamais comme une égale pouvant rivaliser avec lui ${ }^{68}$. Cette tradition rousseauiste a donné naissance à l'idée des 'separate spheres' qui domine dans le monde anglo-saxon pendant la deuxième moitié du XIX ${ }^{e}$ siècle, malgré quelques voix dissonantes comme celle de Margaret Fuller dans Woman in the Nineteenth Century ${ }^{69}$, ou de Harriet Taylor Mill, s'insurgeant en 1851 contre cette idéologie en pleine formation :

We deny the right of any portion of the species to decide for another portion, or any individual for another individual, what is and what is not their 'proper sphere'. The proper sphere for all human beings is the largest and highest which they are able to attain to. What this is, cannot be ascertained, without complete liberty of choice. ${ }^{70}$

Dans Idéologie et utopie ${ }^{71}$, Karl Mannheim, un des premiers et des principaux penseurs de l'utopie, la définit dans un rapport dialectique à l'ordre existant et à l'idéologie qui accepte cet ordre et ses valeurs. Il qualifie d'utopie tout état d'esprit non seulement en opposition avec l'« ordre social réellement existant et pratiquée ${ }^{72}$ » (qu'il appelle la topie ${ }^{73}$ ), mais encore tendant à "ébranler, partiellement ou totalement, [cet] ordre de choses ${ }^{74}$ ». À l'aune de cette définition, News from Nowhere est proprement utopique dans la plupart des domaines, du travail-plaisir à la sexualité, mais idéologique en ce qui concerne la place des femmes. Cet échec à bouleverser les rapports sociaux de sexe est patent dans la plupart des utopies masculines. Par exemple William Dean Howells, auteur comme Morris d'une utopie pastorale en réponse à Looking Backward de Bellamy, fait de longs développements très égalitaristes et progressistes, mais semble les contredire involontairement en construisant de façon cruelle un personnage féminin principal particulièrement stupide ${ }^{75}$. Enfin, bien que Morris ait écrit News from Nowhere pour 
critiquer la vision utopique de Bellamy dans Looking Backward et présenter une alternative, sa vision des femmes diffère bien peu de celle de Bellamy. Chez l'un comme chez l'autre, l'éternel féminin est exalté, les femmes tiennent le rôle d'anges gardiens, récompensent les héros nécessairement masculins de leurs faveurs (sous la forme de doux regards et de sourires) et enfin sont les actrices de l'amélioration eugénique de la race.

\section{NOTES}

1. Toutes les références de pages se rapportent à l'édition suivante : News from Nowhere and Other Writings. Introduction et notes de Clive WILMER. Harmondsworth: Penguin, 1993.

2. Edward BELLAMY, Looking Backward: 2000-1887. Introduction de Cecelia TICHI. New York : Penguin, 1986.

3. Sur cette " chaîne d'utopies ", voir l'introduction de Krishan KUMAR à William MORRIS, News From Nowhere (Cambridge: Cambridge University Press, 1995) et à H.G. WELLS, A Modern Utopia (London: Everyman, 1994).

4. Marie Louise BERNERI, Journey Through Utopia. Préface de George WOODCOCK. London: Routledge \& Kegan Paul, 1950 (London: Freedom Press, 1982). Bien que l'auteure soit une femme, aucune attention particulière n'est portée à la question du genre dans cet ouvrage. Berneri, qui est anarchiste, a beaucoup de sympathie pour News from Nowhere.

5. Arthur Leslie MORTON, The English Utopia, London: Lawrence \& Wishart, 1952 (L'utopie anglaise. Traduit de l'anglais par Jean Vaché. Paris : Maspéro, 1964).

6. Raymond TROUSSON, Voyages aux pays de nulle part : Histoire littéraire de la pensée utopique, Bruxelles : Éditions de l'Université de Bruxelles, 1975 ( $3^{\mathrm{e}}$ édition, revue et augmentée, 1999).

7. Frank E. MANUEL \& Fritzie P. MANUEL, Utopian Thought in the Western World, Cambridge (Massachusetts): Belknap Press of Harvard University Press \& Oxford: Basil Blackwell, 1979.

8. Raymond RUYER, L'Utopie et les utopies, Paris : Presses Universitaires de France, 1950, p. 41.

9. Stephen ARATA, Introduction à William MORRIS, News From Nowhere, Peterborough (Ontario): Broadview Press, 2003, pp. 22-23.

10. Edward BELLAMY, 'News From Nowhere: William Morris's Idea of the Good Time Coming', The New Nation, 14 février 1891, p. 47.

11. Ibid.

12. Fiona MacCARTHY, William Morris : A Life for Our Time, London: Faber and Faber, 1995.

13. On ne parle pas de "féminisme » à l'époque. Nancy Cott commence son livre, The Grounding of Modern Feminism, par un historique du vocabulaire employé et par une mise en garde contre l'usage anachronique et abusif qui est fait du mot 'feminism', lequel n'est entré qu'en 1933 dans le Oxford English Dictionary.

14. L'expression 'Free Love' est beaucoup utilisée au XIX ${ }^{\mathrm{e}}$ siècle, avec un sens sur lequel il convient d'insister un peu car le terme peut prêter à confusion : l'« amour libre » fait du consentement des parties concernées une valeur centrale et signifie donc la liberté et la légitimité pour les hommes et pour les femmes d'entretenir des relations sexuelles du moment que le partenaire a été librement choisi. Par extension, cela implique aussi la liberté et la légitimité à refuser des relations quand celles-ci ne sont pas souhaitées, donc la possibilité pour une femme de se refuser à son mari malgré la loi qui autorise le mari à disposer du corps de sa femme. Les tenants de 
l'amour libre se partageaient entre "exclusivistes " (ceux-ci pensaient que le penchant naturel des hommes et des femmes était de n'avoir qu'un seul partenaire à un moment donné de leur vie) et «variétistes" (plusieurs partenaires). Morris semble se rattacher nettement à la première catégorie, que l'on en juge par News from Nowhere ou par sa correspondance : 'The decent animalism plus the human kindliness: that would be infinitely better than the present system of venal prostitution which is the meaning of our marriage system on its legal side; though as in other matters, in order to prevent us sinking out of existence, real society asserts itself in the teeth of authority by forming genuine unions of passion and affection... The economical freedom of the family would clear away the false sentiment with which we have gilded the chain; but to my mind there would still remain abundance of real sentiment which man has evolved from the mere animal arrangements, and that this would prevent indecencies: though as to the outward form or symbol that it would take I can make no prophecies... The couple would be free'. (Cité dans Peter STANSKY, William Morris, Oxford : Oxford University Press, 1983, pp. 24-25).

15. Paraît pour la première fois en 1879 sous le titre Die Frau und der Sozialismus. Traduit en fançais en 1883, sous le titre de La femme et le socialisme ; traduit en anglais la même année par le socialiste américain Daniel De Leon, sous le titre curieux de Woman Under Socialism (With a new Introduction by Lewis Coser. New York: Schocken Books, 1971). Édition augmentée, 1883, sous le titre: Die Frau in der Vergangenheit, Gegenwart und Zukunft (Woman in the Past, Present, and Future. Translated from the German by H.B. Adams Walther. London: Modern Press, 1885).

16. Friedrich ENGELS, Der Ursprung der Familie, des Privateigenthums und des Staats : Im Anschluss an Lewis H. Morgan's Forschungen (1884). Traduction française : L'origine de la famille, de la propriété privée et de l'État (Pour faire suite aux travaux de Lewis H. Morgan), Paris : Carré, 1893 (Introduction de Pierre Bonte et Claude Mainfroy ; traduction de Jeanne Stern, revue par Claude Mainfroy. Paris : Éditions sociales, 1983). Traduction anglaise : The Origin of the Family, private Property and the State : A Discussion of Lewis H. Morgan's 'Ancient Society'. Chicago : C.H. Kerr \& Co., 1902.

17. News from Nowhere, p. 113.

18. Ibid., p. 91.

19. Ibid., p. 72.

20. Le deuxième exemple est relaté par l'ami de Dick, Walter, lors de l'arrêt des visiteurs à MapleDurham. News from Nowhere, pp. 188-189. Enfin, Ellen explique à Guest : 'I have often troubled men's minds disastrously. That is one reason why I was living alone with my father in the cottage at Runnymede' (ibid., p. 208).

21. 'So it is a point of honour with us not to be self-centred; not to suppose that the world must cease because one man is sorry; therefore we should think it foolish, or if you will, criminal, to exaggerate these matters of sentiment and sensibility: we are no more inclined to eke out our sentimental sorrows than to cherish our bodily pains; and we recognize that there are other pleasures besides love-making'. News from Nowhere, p. 92.

22. C'est Kelmscott Manor qui a inspiré la vieille maison imaginée par Morris comme cadre de la fin de News from Nowhere (voir frontispice p. 134). Sur le processus de transformation littéraire d'une maison dystopique (dans laquelle Morris a assisté impuissant à la liaison de sa femme avec un autre) en maison utopique (abritant les amours fantasmés de Guest et Ellen), voir Paola SPINOZZI, 'And in the Dark House Was I Loved - Writing a Life, Constructing a Utopian Place : William Morris and Kelmscott Manor', in Vita FORTUNATI \& Paola SPINOZZI (ed.), Vite di Utopia, Ravenne : Longo, 2000, pp. 167-177.

23. News from Nowhere, p. 122.

24. William MORRIS, 'A Review of Looking Backward by Edward Bellamy', Commonweal, vol. 5, n`180 (22 June 1889) : 'It must be said that Mr Bellamy has faced the difficulty of economical reconstruction with courage, though he does not see any other sides to the problem, such, e.g., as the future of the family' (Reproduit dans News from Nowhere and Other Writings, op. cit., p. 358). Il est vrai que les seuls 
Bostoniens du futur que Bellamy présente sont une famille WASP composée du père médecin, de la mère et de la fille.

25. Patrick PARRINDER, 'Eugenics and Utopia : Sexual Selection from Galton to Morris', Utopian Studies, vol. 8, n², 1997, pp. 1-12.

26. News from Nowhere, p. 96.

27. Des éléments autobiographiques peuvent expliquer cette attitude: elle a donné naissance toute jeune à un enfant idiot dont les dents n'ont jamais poussé, qui lui a été infligé par le vieux médecin alcoolique qu'elle avait épousé pour échapper à sa famille. Mariée sur le tard à un aristocrate anglais, elle devient de plus en plus eugéniste et lance en 1892 en Grande-Bretagne un journal, The Humanitarian, consacré à cette cause.

28. News from Nowhere, p. 95.

29. Patrick PARRINDER, 'Eugenics and Utopia : Sexual Selection from Galton to Morris', p. 10.

30. J'emprunte librement cette expression de «vision enchantée " à Fiona MacCARTHY : 'The political female, working in the hurly-burly, was clearly disconcerting to a Victorian conditioned to view women in terms of Pre-Raphaelite enchantment'. William Morris : A Life for Our Time, p. 474.

31. News from Nowhere, p. 209.

32. Ibid., p. 193.

33. Au chapitre III, 'The Guest-House and Breakfast Therein', mais aussi au chapitre XVI, 'Dinner in the Hall of the Bloomsbury Market' : 'The pretty waitresses came to us smiling, and chattering sweetly like red warblers by the river-side, and fell to giving us our dinner' (News from Nowhere, p. 130).

34. News from Nowhere, p. 93.

35. Ruth LEVITAS, “ "Who Holds the Hose ?" : Domestic Labour in the Work of Bellamy, Gilman and Morris', Utopian Studies, vol. 6, n¹, 1995, pp. 65-84.

36. News from Nowhere, p. 94.

37. News from Nowhere, p. 94.

38. «La firme » (Morris, Marshall, Faulkner \& Co.) est lancée en 1861 et connaît un grand succès. L'idée que la division étanche et hiérarchique de la société entre manuels et intellectuels est une mauvaise chose est d'ailleurs une préoccupation des intellectuels radicaux, comme en témoigne par exemple aussi le roman de George ELIOT, Felix Holt the Radical (1866).

39. News from Nowhere, p. 66.

40. Fiona MacCARTHY, William Morris : A Life for Our Time, p. 308.

41. News from Nowhere, p. 94.

42. Fiona MacCARTHY, William Morris : A Life for Our Time, p. 137.

43. George Bernard SHAW a ainsi diagnostiqué le rôle de Jane Morris comme étant d' être belle ": 'she knew that to be so was part of her household business' (Cité dans Fiona MacCARTHY, William Morris : A Life for Our Time, p. 137). Morris détestait la reine Victoria et Fiona MacCarthy émet l'hypothèse que la laideur de la vieille reine était peut-être en grande partie responsable de cette détestation (Ibid., pp. 408-409).

44. Anthea CALLEN, The Angel in the Studio: Women in the Arts and Crafts Movement, 1870-1914, Londres : Astragal Books, 1979.

45. News from Nowhere, p. 53.

46. Exemples: News from Nowhere, pp. 61 et 63.

47. News from Nowhere, p. 163.

48. News from Nowhere, pp. 75-76.

49. Ibid., p. 196.

50. Barbara WELTER, 'The Cult of True Womanhood : 1820-1860', American Quarterly 18, Summer 1966, p. 165.

51. News from Nowhere, p. 72.

52. Ibid., p. 55.

53. News from Nowhere, p. 56. 
54. 'Coaxingly', ibid., p. 57.

55. 'Of all the persons I had seen in that world renewed, she was the most unfamiliar to me, the most unlike what I could have thought of. Clara, for instance, beautiful and bright as she was, was not unlike a very pleasant and unaffected young lady; and the other girls also seemed nothing more than specimens of very much improved types which I had known in other times. But this girl was not only beautiful with a beauty quite different from that of "a young lady", but was in all ways so strangely interesting' (ibid., p. 203).

56. News from Nowhere, p. 208.

57. Ibid., p. 217.

58. Gabrielle HOUBRE, La discipline de l'amour : L'éducation sentimentale des filles et des garçons à l'âge du Romantisme, Paris : Plon, 1997, pp. 159-160.

59. News from Nowhere, p. 57.

60. Ibid., p. 210.

61. Ibid., p. 210.

62. News from Nowhere, pp. 129, 165, 213, 214, 219.

63. News from Nowhere, p. 129. De même avec Annie : 'Annie shook hands with me, and hoped I had had a pleasant day - so kindly, that I felt a slight pang as our hands parted' (ibid., p. 165).

64. News from Nowhere, p. 130.

65. Encore un exemple dans le texte : 'I felt that disappointed kind of feeling which overtakes one when one has seen an interesting or lovely face in the streets which one is never likely to see again' (p. 63).

66. Morris écrit dans une lettre à un ami : 'Copulation is worse than beastly unless it takes place as the outcome of natural desires and kindliness on both sides! So taking place there is even something sacred about it in spite of the grotesquery of the act... mere animal on one side, inexplicably mysterious on the other'. Cité dans Peter STANSKY, William Morris, p. 24.

67. News from Nowhere, p. 228.

68. Jean-Jacques ROUSSEAU, Émile ou De l'éducation, 1762 (Paris : Gallimard, 1969, pp. 528-662).

69. Margaret FULLER, Woman in the Nineteenth Century (1845), in Donna DICKENSON (ed.), Woman in the Nineteenth Century and Other Writings, Oxford: Oxford University Press, 1994. Bien qu'elle croie à une nature féminine différente de la nature masculine, Margaret Fuller souhaite que soit mis un terme à la stéréotypie sexuelle et que les femmes puissent exercer tous les métiers, même capitaine au long cours.

70. Harriet TAYLOR MILL, 'The Enfranchisement of Women', in Ann P. ROBSON \& John M. ROBSON (eds.), Sexual Equality : Writings by John Stuart Mill, Harriet Taylor Mill and Helen Taylor, Toronto: University of Toronto Press, 1994, p. 186.

71. Karl MANNHEIM, Ideologie und Utopie, Bonn : F. Cohen, 1929 (Idéologie et utopie. Préface de Louis Wirth, traduction française partielle de Pauline Rollet, à partir de la traduction anglaise, Ideology and Utopia [London: Kegan Paul, Trench, Trubner \& Co., 1936]. Paris: Marcel-Rivière, 1956).

72. Ibid., p. 126.

73. Ibid., p. 126.

74. Ibid., p. 124.

75. William Dean HOWELLS, A Traveler from Altruria. Première édition en feuilleton in Cosmopolitan, novembre 1892-octobre 1893. Première édition sous forme de livre : A Traveler from Altruria : Romance, New York: Harper \& Brothers, 1894. Edited with an introduction by David W. LEVY. Boston \& New York: Bedford Books of St Martin's Press, 1996. 


\section{RÉSUMÉS}

Quelle place l'utopie de William Morris réserve-t-elle aux femmes? Libertaire dans sa vision globale, Morris l'est aussi dans sa vision des relations entre les sexes dans la société communiste sans État qu'il appelle de ses vœux. Néanmoins, Morris est aussi sensible aux sirènes de l'eugénisme et réserve aux femmes dans sa construction utopique les tâches ménagères. Bien que socialiste marxiste, il reste un esthète victorien pour qui la femme du futur doit obligatoirement être belle et bonne, et dont l'utopie est une fête des sens, compensatoire des frustrations de sa vie.

What is the position of women in William Morris's utopia? As in his overall utopian vision, Morris maps out a libertarian vision of the relationships between men and women in the stateless communist society he hankers after. For all that, Morris lends his voice to the theme of eugenics and confines his utopian women to domestic work. Though a Marxian socialist convert, Morris never ceased to be a Victorian aesthete in whose view the woman of the future can be nothing but supremely beautiful and benevolent, and whose utopian construct gives pride of place to sensual pleasure so as to compensate the frustrations of his actual life. 